\title{
Impact of Storage Devices with Renewable Integrated Distribution Network for Power Loss Minimization
}

\author{
Bharat Singh, Satyaveer Singh Rawat
}

\begin{abstract}
The intermittent behaviour of renewable energy generation has become an essential issue for power deficiency in the distribution network. The high penetration of wind and solar became the primary task for the optimal size of energy storage to support the power mismatch. In the present work, the impact of the energy storage device with distribution generation (DGs) have been determined in a renewable integrated distribution system for power loss minimization. The main contribution of this paper is: (i) optimal location of DGs and battery are obtained by solving single and multi-objective functions. (ii) Determination of DG and battery size for minimization of power loss and system cost. (iii) Impact of battery energy storage device on loss profile and total cost of the system. The impact of day load variation has been considered in the study. The results have been obtained for IEEE-33 bus test system using a hybrid GAMS and particle swarm optimization (PSO) algorithm. The power loss is reduced to 47.60\% with single DG and battery energy storage (BES). In addition, the power loss is reduced to $59.285 \%$ with two DGs and BES. The simulation results of the test system have been compared with other existing results.
\end{abstract}

Keywords: Radial distribution system, Power Loss minimization, Battery energy storage device, PSO and GAMS, Renewable Energy Resources.

\section{INTRODUCTION}

$\mathrm{P}$ wer loss reduction is a significant issue for Renewable energy planning in the Distribution system. The losses along the distribution system are much higher with a higher value of $\mathrm{R} / \mathrm{X}$ component of the line as compares to the transmission system. Therefore, the loss minimization in distribution system has become an essential issue. Many of the utilities have been used to compensate for the loss in the distribution network. Therefore, the location and sizing of DGs is the major issue in the distribution network. The coordination of energy saving with the overall cost of the system is another issue in the system. The integration of renewable energy sources and their generation in the MG has constituted more challenges for the control and operation in the power system. There is some crucial problem to be solved to mitigate the

Manuscript received on February 19, 2021.

Revised Manuscript received on February 28, 2021.

Manuscript published on February 28, 2021.

* Correspondence Author

Bharat Singh*, Electrical Engineering Department, NIT Kurukshetra, Haryana, India. Email: bharat6180045@nitkkr.ac.in

Satyaveer Singh Rawat, Electrical Engineering Department, G.B. Pant Institute of Engineering \& Technology Ghurdauri, Pauri Garhwal, Uttarakhand, India. Email: satya.firststep@gmail.com, ssr09fee@gbpec.ac.in

(C) The Authors. Published by Blue Eyes Intelligence Engineering and Sciences Publication (BEIESP). This is an open access article under the CC BY-NC-ND license (http://creativecommons.org/licenses/by-nc-nd/4.0/) intermittencies, load demand, voltage stability and power mismatch. The solution has identified using the energy storage system to store the electric energy at the surplus and supply when needed [1]. Furthermore, the optimal sizing and location of the Distribution Generations (DGs) along with the ESS have required in order to solve the techno- economic problem with the distribution network constraints. In this context, the optimal size and location of the DGs and BES must be determined accurately in the multi-objective scenario. Moreover, the appropriate finding of the optimization algorithm is another task for solving the multi-objective problem. Furthermore, the main motivation of this paper is; (i) the optimal location and size of battery energy storage integrated with the renewable-based DGs have to be determined. (ii) The energy-saving and the minimum operating cost of the system must be found with the influence of battery energy storage. (iii) The hybrid PSO and GAMS algorithm has been proposed to solve the multi-objective problem. A lot of literature is available for optimal placement of DGs to minimize the power loss and voltage deviations in a network. In this regard, various algorithms have been used for determining the location and size of the DGs. Authors [2] presented the annual energy loss minimization with the integration of DGs in the network. The optimal DG placement using Stud Krill herd Algorithm (SKHA) for the radial distribution system in [3]. Although, the Krill herd (KH) algorithm has failed to select the global optimal solution in search space. The population-based Gbest-guided Artificial Bee Colony (GABC) optimization algorithm has used to minimize the power loss and determine the impact of shunt capacitor with DG placement [4]. Many of the literature is based on the nature-inspired algorithm. In this way, the optimal location of DG has been obtained by using Dragonfly algorithm [5]. An improved particle swarm optimization has been used for the installation of DG in Microgrid (MG) system [6]. The analytical representation is used to obtain the size of DG at various locations for total loss minimization in [7]. The loss saving equations was also represented in [7]. The different types of voltage-dependent loads and a separate line $\mathrm{XR}$ ratios have taken into account to study the distribution load flow [8]. Murty et al. [9] have considered the multi-objective based optimization problem for the uncertainty nature of renewable power generation. The reactive power support has also been done using the installation of DG location in [10]. The optimal power factor has considered for the position of DG to minimize the power loss using PSO algorithm by Kansal et al. [10].

Published By: 
The Mixed Integer Non-Linear Programming (MINLP) formulation has introduced in [11] for loss minimization. The DG location has been obtained by combined power loss sensitivity (CPLS) approach; however, the battery storage was not considered.

The DGs installation has been considered for generation and load shedding cost using the Lightning search algorithm (LSA) [12]. The clearness index of probability density function (pdf) has been used along with Monte Carlo simulation (MCS) to model the solar irradiance [13]; however, the battery energy support has not considered. MG with four different types of DG has obtained to minimize power loss and to regulate the bus voltage also. In the literature [1-11] the power loss scenario-based optimal location of DGs was obtained. Yet, battery storage has not been found in the literature [1-11]. A lot of the literature has found the dispatch strategy for the battery storage installation and sizing. In this regard, the combined dispatch strategy for battery storage along with PV-Diesel system has been implemented in the HOGA (Hybrid Optimization by Genetic Algorithms) program [14]. Moreover, the Genetic Algorithm (GA) has been used. Although, the GA has the significant disadvantage of its prolonged convergence rate since the unguided mutations [15]. The wind-based Distribution generation (DG) has not considered. The multi-source based hybrid generation with battery storage using PSO algorithm has been taken into account to minimize the total power loss in [16]. The battery size determination has reviewed in [17] with various indicators likewise, financial, technical and hybrid indicators. Furthermore, these indicators are as follows; In the Financial index, the local currency has become the decision making for the benefit and overall cost of the battery in renewable energy sources (RES). The net present value (NPV) of the battery energy storage system (BESS) [18] has represented to achieve the sizing and placement of ESS. An optimal scheduling analysis for the vanadium redox battery (VRB) has described based on cost-benefit review for MG application [19]. In the technical index, the ESS has to support the dynamic and steady-state behaviour of RES in the MG system. The risk-informed decision-making process has introduced to obtain the size of battery storage by using the probabilistic approach [20]. In the composite index, the battery size has been obtained by considering both financial and technical indicators. The size of battery storage has been determined by considering the electricity market for the wind power plant [21]. The battery storage has also been emphasized the operation and economics of the wind power intermittency. In this paperwork, the composite index has been taken into account for the techno-economic analysis for battery energy installation. The metaheuristic techniques have used to obtain the sizing and location of the BESS system. The improved bat algorithm has used to obtain the size of storage devices in an economic environment [22]. Although, the BAT algorithm has a drawback of being trapped in local optima in some cases. The reliability improvement has considered for the sizing of battery storage in a radial electrical distribution network [23]. However, the MINLP has solved within the PSO algorithm. The PSO algorithm has also used to obtain the optimal sizing of BESS for improved frequency control of system [24]. The economic benefit has maximized in [25], with the BESS and wind farm by considering the voltage of DC link to remains in the limit. The size and location of battery storage devices were obtained using flexible energy management (FEM) in the distribution system [26]. Although, the main drawbacks of the PSO algorithm are untimely convergence, drop down to reginal optimal point and not enough multiplicity of population founded [15]. Therefore, selecting a robust and strong revolutionary algorithm in order to solve the complex multi-objective problem has an important role. One of the new hybrid algorithms which have great potential is Particle Swarm Optimization (PSO). PSO is a well-known optimization technique created by J. Kennedy and R. Eberhart in 1997 [27]. Moreover, it includes minimal storage requirement, very fast to converge, very fast researching speed, easy to use, no overlapping, no mutation calculation and have the simplicity [24]. With this reason, in this paper, the PSO algorithm is selected as a proposed algorithm. The hybrid optimization of PSO with GAMS has been used to overcome multiplicity in a population of PSO in this paperwork. The BES has been considered for the energy dispatch in a microgrid in literature[28], although the dispatch strategy was not considered for the BES installation. The combined dispatch (CD) control strategy; comprises the load following (LF) strategy and cycle charging (CC) strategy has studied for hybrid energy sources [29]. The net present cost (NPC) and the cost of energy (COE) values have compared with using different control strategy also. Therefore, the paper proposed and investigated the optimal sizing and location of battery energy storage along with DGs. Moreover, the combined dispatch strategy for the installation of the battery storage has been used in this paper. As evidenced by the literature review, the main research gaps can be summarised as:

- Lack of solution for the optimal sizing and location of the BES along with the DGs have not been considered with both multi-objective and composite indexed based scenario.

- Most of the optimization algorithm has been solved for this regards and have a lot of advantages as well as disadvantage. Therefore the appropriate algorithm has to be needed to find.

- Most of the literature is based on the installation of the battery storage, but very few of them has used the dispatch strategies. Moreover, for the optimal location and sizing of storage devices, the battery dispatch strategy must be taken into account for the best control and benefit.

Therefore, the purpose of the present work to address this research gap and the key contribution may be summarised as follows;

- The composite index has been taken using the combined dispatch strategy for the installation of battery energy storage.

- The optimal sizing and location of DGs with BES has been determined to achieve the daily energy loss saving and minimum operating cost of the system.

- The robust and strong revolutionary hybrid PSO and GAMS algorithm has been proposed for solving the complex multi-objective problem.

ublished By:

Blue Eyes Intelligence Engineering and Sciences Publication (C) Copyright: All rights reserved.

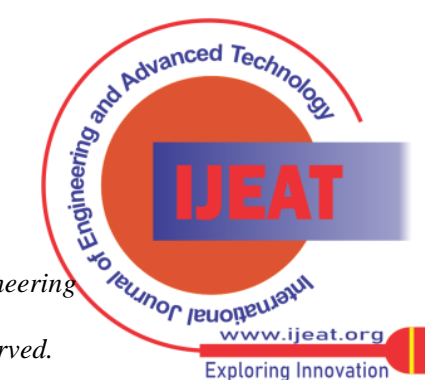


Which can improve fast and smooth control for the results, decreased the daily energy loss and the operating cost of the system. Furthermore, the hybrid optimization has been carried out in two parts as follows:

(i) First, the optimal location of BSS and DGs are obtained using PSO algorithm.

(ii) Then, the optimal size of BSS and DGs are obtained using MINLP algorithm in GAMS.

The hybrid algorithm has been carried out for both single and multi-objective taken for the analysis. The PSO has been utilized to obtain the optimal global position in the network, and then sizing has been obtained using GAMS. The analysis has been carried out to obtain the daily energy savings with DGs and the impact of battery energy device on the savings.

\section{PROBLEM FORMULATION}

The main objective of the paper is; to obtain optimal location and size of DG along with battery storage devices for minimization of the Daily energy loss of the network. The single and multi-objective have been considered for the analysis.

The single objective problem has formulated as:

- Minimize the Daily energy loss with DGs and battery storage devices.

In this paper, the problem has been solved in two parts. In the first part; the location of DGs has obtained determining the Daily energy loss minimization using PSO (Particle Swarm Optimization) algorithm. The location of battery storage has been obtained using the combined dispatch strategy in the PSO algorithm.

In the second part: (ii) the size of DGs and battery storage was obtained solving the problem with the MINLP (Mixed Integer Non-Linear Programming) in GAMS.

The multi-objective problem was formulated as:

- Minimization of the cost of Daily energy loss.

- Minimization of the total daily cost of the system for 24-hour load cycle.

The total cost of the system consists of the cost of energy loss (CEL), the fuel cost of diesel generator, operation and maintenance cost, replacement cost, and initial installation cost of DG, PV, battery, regulator, invertors etc.

The problem has been solved first finding the optimal location and then the DGs and battery sizes as for the single objective problem.

The results are obtained for location, sizes, loss profile, cost of energy loss, total cost, energy savings, and voltage profile of the system. The fuel cost of diesel generator, along with the operational and maintenance costs are also obtained. The analysis has been carried out, taking one and two DGs in a network.

\section{A. Mathematical Model}

In this section, the mathematical modeling of DGs, solar, wind and battery energy storage has been represented as follows;

Single objective function:

(i) Minimization of the annual cost of energy loss as:

$$
O F 1=365 \times C_{\text {lose }} \times \sum_{k=1}^{T}\left(\sum_{j=1}^{n l} P L_{i j}\right) \cdot \Delta k
$$

where, $P L_{i j}$ is the total active power loss in the line respectively. $\Delta k$ is the time duration in hrs. The cost coefficient for the loss $C_{\text {lose }}$ is 60 ( $\left.€ / \mathrm{MWh}\right)$.

Multi-objective function:

(ii) Minimization of cost of energy loss and the cost of the DGs as:

$$
\begin{aligned}
& O F 2=\min \left\{\text { TotalCost }_{\text {Batt }}+\text { TotalCost }_{\text {O\&M }}+\right. \\
& \left.\left(\text { Cost }_{D G}^{\text {Ren }}+\text { Cost }_{D G}^{\text {Diesel }}\right)\right\}
\end{aligned}
$$

where,

TotalCost $_{\text {Batt }}=\sum_{k=1}^{T}\left\{\sum_{i=1}^{n b}\left(N_{\text {inv }}(i) \cdot\right.\right.$ Cost $_{\text {inv }}+N_{\text {batt }}(i) \cdot$

Cost $\left._{\text {hatt }}\right)$ \}

$\operatorname{Cost}_{D G}^{\text {Diesel }}=\operatorname{Pr}_{\text {fuel }} \cdot\left(\sum_{i}^{n b}\right.$ fuel $\left.l_{\text {consumed }}\right) \cdot T$

$\operatorname{Cost}_{D G}^{R e n}=\sum_{k=1}^{T}\left(\sum_{i}^{n b}\left(N_{P V}(i) \cdot \operatorname{Cost}_{P V}+N_{\text {wind }}(i)\right.\right.$.

Cost $_{\text {wind }}+N_{\text {reg }}(i) \cdot$ Cost $\left._{\text {reg }}\right)$ )

The net present value for all components are given as:

TotalCost $_{\text {OsM }}=$ Cost $_{\text {Aqu }}+$ Cost $_{\text {osu }}+$ Cost $_{\text {Rep }}$ (4)

Cost $_{\text {Aqu }}$, is the acquisition cost, $C_{e}$ is cost of the energy loss, Cost $_{\text {OSRM }}$ is the operation and maintenance cost, Cost $_{\text {Rep }}$ is the replacement cost. The values of the parameters are given in the Table-I. $N_{P V}, N_{\text {wind }}, N_{\text {batt }}, N_{\text {reg }}, N_{\text {inv }}$ is the number of PV panel, wind turbine, battery, regulator, invertors respectively. Cost post $_{\text {wind }}$, Cost batt $_{\text {, }}$ Cost reg $_{\text {, }}$ Cost $_{\text {in }}$ is the net present cost for PV, wind, battery, regulator, and inverter respectively. fuel conswmed $_{\text {is }}$ fuel consumed by the DEGs, $P_{r_{f u e l}}$ is the fuel price (litter $/ \mathrm{kWh}$ ), and $\mathrm{T}$ is the total time period of operation.

The equality and inequality constraints are:

1) Optimal power flow formulation

$$
\begin{aligned}
& P_{i}^{k}=\left(P g_{i}^{k}-P d_{i}^{k}\right)=V_{i}^{k} \sum_{j=1}^{n} V_{j}^{k}\left(G_{i j}^{k} \cos \left(\delta_{i}^{k}-\delta_{j}^{k}\right)+\right. \\
& \left.B_{i j}^{k} \sin \left(\delta_{i}^{k}-\delta_{j}^{k}\right)\right) \\
& Q_{i}^{k}=\left(Q g_{i}^{k}-Q d_{i}^{k}\right)=V_{i}^{k} \sum_{j=1}^{n} V_{j}^{k}\left(G_{i j}^{k} \sin \left(\delta_{i}^{k}-\delta_{j}^{k}\right)-\right. \\
& \left.B_{i j}^{k} \cos \left(\delta_{i}^{k}-\delta_{j}^{k}\right)\right)
\end{aligned}
$$

$\forall i \in S_{B} \& k \in S_{T}$

where $S_{B}$ is the set of buses, and $S_{T}$ is the set of Time k. $P d_{i}^{k}$ and $Q d_{i}^{k}$ are the active and reactive power demand for $\mathrm{i}^{\text {th }}$ bus at $\mathrm{k}^{\text {th }}$ time period.

Inequality constraints:

2) Power generation

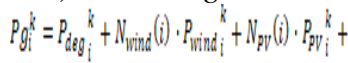

$N_{b a t h}(i) \cdot\left(P_{c h i}^{k}-P_{\text {disi }}^{k}\right)$

$$
Q g_{i}^{k}=Q_{\operatorname{deg}_{i}^{k}}^{k}+N_{\text {wind }}(i) \cdot Q_{\text {wind }_{i}}^{k}
$$

where, $P_{\operatorname{deg}_{i}}{ }^{k}$ and $Q_{\operatorname{deg}_{i}}{ }^{k}$ are the active and reactive power supplied by a diesel generator for the $\mathrm{i}^{\text {th }}$ bus at the $\mathrm{k}^{\text {th }}$ period.

3) Power Loss

$\left|P L^{k}\right|=\left|P_{i j}^{k}\right|=\mid V_{i}^{k} \eta_{j}^{k}\left(G_{j i}^{k} \cos \left(\theta_{j}^{k}-\right.\right.$

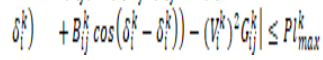

where, $P l_{\max }^{k}$ is the maximum apparent power flow through the line at kth hrs. $l \in S_{L}$ is the set of the line.

Published By:

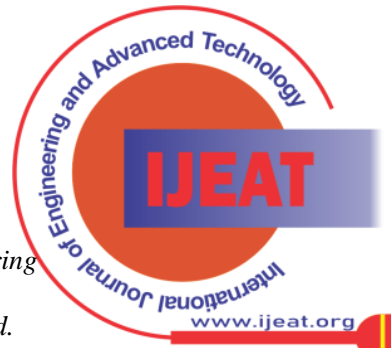


4) Transmission line sending end and receiving end constraints

$$
\begin{aligned}
& P_{f g \min _{j}}^{k} \leq P_{f s_{j}} \leq P_{f s \max _{j}{ }^{k}}^{k} \quad i \in S_{f s} \\
& Q_{f o m i n_{i}}{ }^{k} \leq Q_{f s_{j}} \leq Q_{f o m a x}{ }^{k} \text {, } i \in f s r \\
& P_{f r m i n}^{k} \leq P_{f y_{j}} \leq P_{f r m a x}^{k} k_{j}^{k} \quad i \in S_{f y} \\
& Q_{f_{\text {frmin }}}^{k} \leq Q_{f_{j}} \leq Q_{f_{\text {frmax }}{ }_{j}^{k}} \text {, } i \in S_{f y}
\end{aligned}
$$

5) Limits of the capacity of the distribution system

$$
\begin{aligned}
P_{G i}^{\min } & \leq P_{g_{i}} \leq P_{g i}^{\max }, i \in S_{G} \\
Q_{g i}^{\min } & \leq Q_{g_{i}} \leq Q_{g i}^{\max }, i \in S_{G}
\end{aligned}
$$

6) Limits for voltage and angle

$$
V_{i}^{\min } \leq V_{i} \leq V_{i}^{\max }, i \in S_{B}
$$

7) Limits for voltage and angle

$$
\delta_{\min _{j}}^{k} \leq \delta_{i} \leq \delta_{\max _{j}}^{k}, \forall i=1,2 \ldots n b
$$

8) Power factor limits

$$
p f_{i}^{l 0} \leq p f_{i} \leq p f_{i}^{u p p}, i \in S_{B}
$$

B. Mathematical modelling of energy sources

In this section, the mathematical modelling of renewable-based DGs, diesel generator based DG and battery energy storage are given.

1) PV Panel modeling

The PV generator is the renewable source which provides the DC current at $48 \mathrm{~V}$. The Monte Carlo Simulation (MCS) has been taken for the exact modeling of solar power output. In this scenario, 1000 numbers of the sample have been taken for simulation.

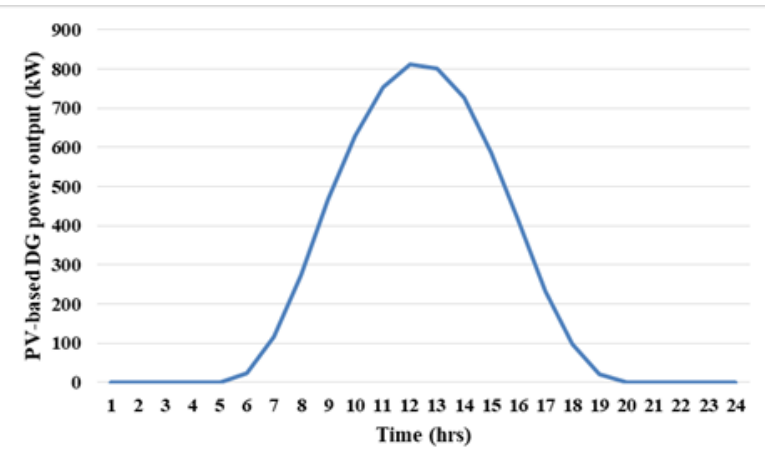

Figure 1 Solar power output curve for $\mathbf{2 4}$ hrs

The solar PV model is:

$P_{\text {Solar }}\left(I_{\beta}\right)=N_{P V} \cdot F F \cdot V \cdot I$

where, $P_{\text {solar }}$ is the output power, $F F$ is the fill factor, $V$ is the rated voltage, $I$ is the current output, and $N_{P V}$ is the total number of the solar panel [13]. The Figure1 shows the solar PV-based DG power output for 24 hrs.

2) Wind model

In this paper, the quadratic model of wind has been taken. The wind turbine model is as:

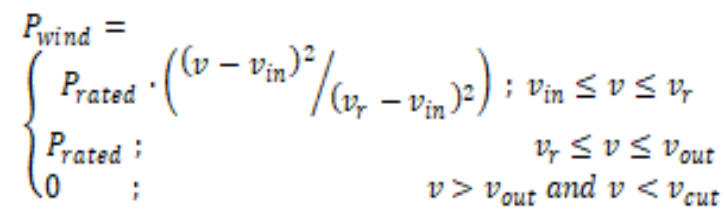

where, $P_{\text {rated }}$ is the rated wind power, $P_{\text {wind }}$ is the wind power output. $v_{\text {in }}$ is cut in the velocity of wind, $v_{\text {out }}$ is cut out wind velocity. Figure 2 shows the wind turbine power output curve.

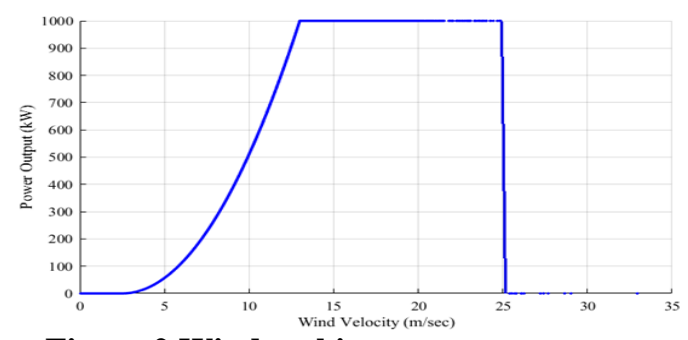

Figure 2 Wind turbine power output curve

\section{3) Battery model}

The battery storage works as backup storage. The discharging and charging power limits of battery are the control parameters. These parameters depend on the dispatch strategy [29]. The state of charge has been calculated for each battery in such a way to balance the power. The maximum value depends on the nominal capacity, while the minimum amount depends on its Depth of Discharge (DOD).

$$
\begin{aligned}
& S O C_{\min }=N_{b a t} C_{n}\left(1-D O D_{\text {max }} \text { bat }\right) \\
& S O C_{\max }=N_{b a t} C_{n} \\
& \operatorname{soc}(k+\Delta k)=\operatorname{soC}(k) \cdot(1-\delta)+\left(P_{\text {chn }} \cdot \eta_{\text {ch }}-\right. \\
& \left.P_{\text {dis }} \div \frac{1}{p_{\text {dix }}}\right) \cdot \Delta k
\end{aligned}
$$

$$
E_{b a t t}(k)=\left[\max \left(S O C_{i}(k)\right)-\min \left(S O C_{i}(k)\right)\right] \cdot V_{D C}
$$

Where, $D O D_{\max }$ bat is the maximum depth of discharge, $C_{n}$ is the nominal capacity (Ah), $N_{b a t}$ total number of battery, $S O C$ is a state of charge, $P_{c h}$ charging power, $P_{\text {dis }}$ is discharging power, $\eta_{c h}$ and $\eta_{\text {dis }}$ are the charging and discharging efficiency of the battery. $E_{b a t t i}$ is the energy capacity in (kWh) and $V_{D C}$ is the DC bus voltage.

Constraints:

$$
\begin{aligned}
& \operatorname{SOC}_{i}^{\min }(k) \leq \operatorname{SOC}_{i}(k) \leq \operatorname{SOC}_{i}^{\max }(k) \\
& N_{b a t}(i) \cdot P_{c h_{-} \min _{i}}^{k} \leq P_{c h_{i}^{k}}^{k} \leq N_{b a t}(i) \cdot P_{c h_{-} \max _{i}}^{k} \\
& N_{\text {bat }}(i) \cdot P_{\text {dis } \min _{i}}^{k} \leq P_{\text {dis }}^{k} \leq N_{\text {bat }}(i) \cdot P_{\text {dis_max }}^{k}
\end{aligned}
$$

where, $\hat{i}$ is the total number of buses in the network .i.e. $P_{c h} \min$ and $P_{\text {ch max }}$ are the maximum and minimum charging power limits for 24 hrs of the battery, respectively.

4) Combined Dispatch Strategy

In this paper, the combined dispatch strategy is implemented for the location of the energy storage device. In the combined dispatch strategy, the load following (LF) and cycle charging (CC), both strategies have been used [16]. The decision parameters for dispatch strategy are critical discharging load $\left(L_{d}\right)$ and the critical charge load $\left(L_{e}\right)$. The Ld and Lc are formulated as follows;

$$
L_{c}=\left(L_{\text {deg }} * \eta\right) / L_{c e}
$$

$$
L_{d d}=\left(\eta_{\text {inv }} * L_{\text {deg }}\right) /\left(C_{\text {cyelbatt }}-\eta_{\text {inw }} * A * P_{\gamma_{\text {fuel }}}\right)
$$
where the $L_{\text {deg }}$ is the net cost coefficient of diesel generator, $L_{c c}$ is cycle charging coefficient for battery and formulated as;

$$
\begin{gathered}
L_{\text {deg }}=B \cdot P_{\text {NGen }} * P_{r_{\text {fuel }}}+\text { Cost }_{\text {osigen }}+\text { Cost }_{\text {Rep }} \\
L_{c e}=\eta_{\text {eh }} \eta_{\text {batt }} * C_{\text {cyelbatt }}+\left(1-\eta * A * P r_{\text {fuel }}\right)
\end{gathered}
$$

where $\eta=\eta_{c h} * \eta_{b a t t} * \eta_{i n v}$ is the overall efficiency, $\eta_{c h}$, $\eta_{\text {batt }}, \eta_{\text {inv }}$ are the efficiency of the charger, battery and inverter respectively.

Published By:

Blue Eyes Intelligence Engineering and Sciences Publication 
$C_{\text {cyrlibatt }}$ is the cost of cycling energy [14]

The value of net DC load $\left(P d_{\text {net_ }} \operatorname{Load}_{i=i d q}\right)$ for the highest at the bus is given as

$$
P d_{\text {net_Load }}^{k}=P d_{\text {net_Load }}^{k}{ }_{i}^{k}-\left\{P_{P V i}{ }^{k}+P_{\text {wind }}^{k}\right\}
$$

According to the combined dispatch strategy;

If $\left\{\begin{aligned} P d_{\text {net_Lond }}^{k}<L_{i} ; \text { Cycle charging strategy } \\ P d_{\text {net_Load }}^{k}>L_{d^{*}} \text { Load following strategy }\end{aligned}\right.$

where the value of the bus $\left(\mathrm{i}_{\mathrm{dg}}\right)$ is obtained by solving the PSO approach. Initially the value of $P_{D E G 0_{i}^{k}}$ is taken as the rated value of diesel generator of $4 \mathrm{~kW}$. The value of $P_{D E G O}{ }_{i}^{k}$ is used for finding the cost coefficient for diesel generator (26) and location only.

In the proposed algorithm, the PSO, along with combined dispatch strategy, has been used for obtaining the location of DGs and battery storage devices.

The combined dispatch strategy is depicted in Figure 3, which comprises the cycle charging and load-following strategy. The load following strategy aims to meet the demand. The priority is to meet the load demand with renewable sources of energy. The backup sources are met the load demand in case the net load $\left(P d_{\text {net_Lond }}^{k} d_{i=i d g}\right)$ exceeds the demand. Which is mainly based on the critical discharging load $\left(L_{d \in}\right)$. On the other hand, the cycle charging strategy is used when the battery storage is not able to meet. In the cycle charging strategy, the diesel generator is operated at full capacity, and it does not exceed the battery charging power. Moreover, the diesel generator is a continuous run to meet the demand and charge the BES also.

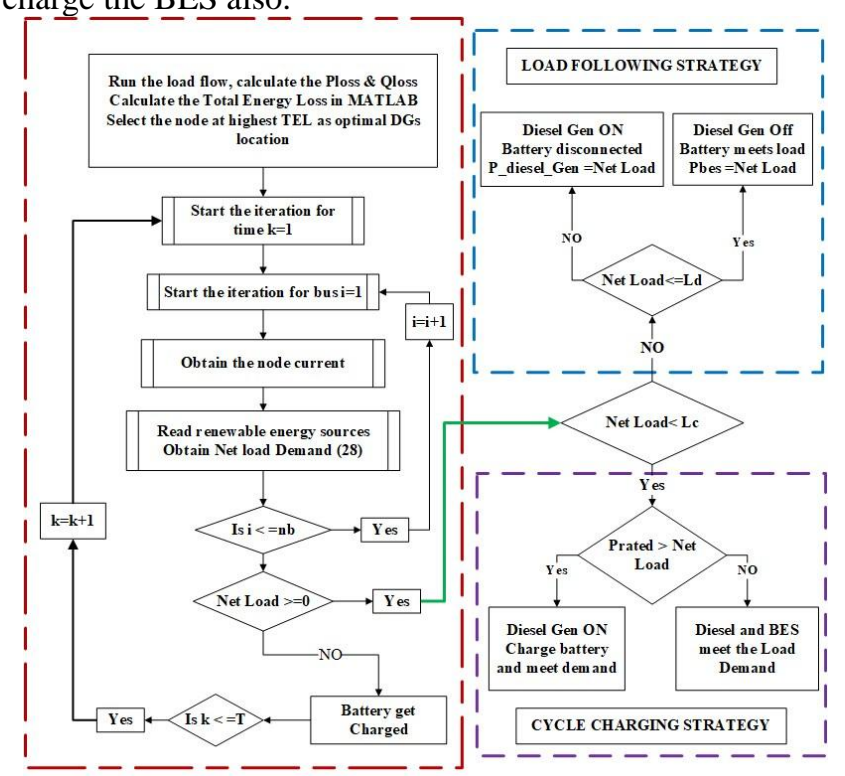

Figure 3. The combined dispatch strategy

5) Radial Distribution system

The radial distribution system comprises of the source at one node and load at the end connected node with the help of line. The designed power generation system consists of the static load for 24 hrs of variation, solar PV-based DG, wind-based DG, diesel generator- based DGs and batteries. In Figure 4, the equivalent circuit model of a radial distribution system is represented.

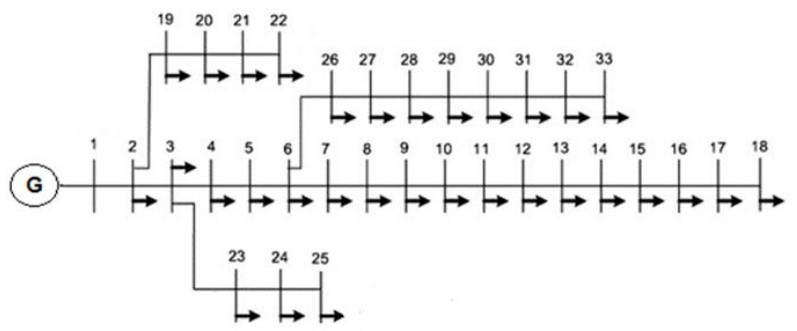

Figure 4 IEEE-33 bus radial distribution test system

\section{ALGORITHM}

In this section, the various steps have explained to solve the optimization problem using MINLP solver in GAMS. The MATLAB and GAMS interfacing has also been described in this algorithm for solving the hybrid optimization algorithm.

\section{A. Implementation of PSO algorithm}

The following steps have implemented for solving the large scale nonlinear problem.

- First, the PSO has initialized in multidimensional search space along with a population of particles having random position and velocity.

- The comparisons of each particle have made with its best position, i.e. P_best. For global best (g_best), the best fitness value of objective function has selected. If the current value is better than neighbour value, the g_best and p_best, have been updated respectively.

- The velocity and position have been updated for each particle in multidimensional search space by using equations as follows;

where

$$
\begin{aligned}
& v_{i}^{i t e r+1}=w \cdot v_{i}^{\text {iter }}+c_{1} \cdot \text { rand }_{1} \cdot\left(p_{- \text {best }}^{\text {iter }}-s_{-i}^{\text {iter }}\right)+c_{2} \cdot \\
& \text { rand }_{2} \cdot\left(g_{-i \text { est }}^{\text {iter }}-s_{-}^{\text {iter }}\right) \\
& s_{i}^{\text {iter }+1}=s_{-i}^{\text {iter }}+v_{i}^{\text {iter }+1}
\end{aligned}
$$

where $\mathrm{w}$ is weight function given as

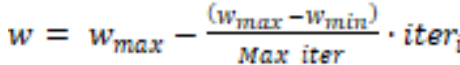

The PSO parameters take are $\mathrm{c} 1=\mathrm{c} 2=2, \quad \mathrm{w} \_\max =0.9$, w_min=0.4, Max_iter=100. The PSO algorithm has been used to obtain the optimal location of DGs and battery storage to minimize the Daily energy loss.

\section{B. The hybrid PSO and GAMS algorithm}

In the proposed hybrid optimization algorithm from step 1 to 4; the PSO algorithm has used. Whereas in step 5 to step 8, the MINLP solver in GAMS has used for obtaining the size of DGs and battery storage.

Step1

(a) Initialize the random population for PSO algorithm.

(b)Solve the equation for wind and solar power calculation.

Step 2

(a) Run the load flow program for 24-hrs and obtain the base Case Daily energy loss using PSO algorithm.

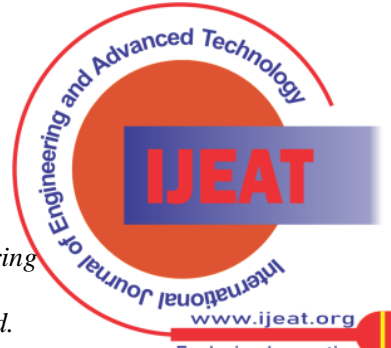


(b)Select the candidate node having the highest energy loss for DG location. Save the place for DGs.

Step 3 Solve the combined dispatch strategy for each buses $\mathrm{i}=1$ to $\mathrm{nb}$ and $\mathrm{k}=1$ to $24 \mathrm{hrs}$.

(a) Obtain the position of batteries at each node determining the net load current from step 2(a).

(b) The iteration for $\mathrm{i}^{\text {th }}$ bus and $\mathrm{k}^{\text {th }}$ time solve up to $i \leftarrow i+1 ; k \leftarrow k+1$. If $i<n b$ and $\mathrm{k}<T$; go for step 2 otherwise go to next step.

Step 4. After obtaining the location of the candidate node, the size of DGs, along with battery storage, has determined. Transfer the all control parameter from MATLAB to GAMS.

(a) Solve the objective function (1) and (3). Solve the constraints equation from (5) to (15) calculate the SOC using MINLP solver.

(b) Obtain the size of the battery (20), SOC, charging and discharging of the cell, and solve equation (21) and (22).

(c) Obtain the size of DG by solving constraints (24) and (29)

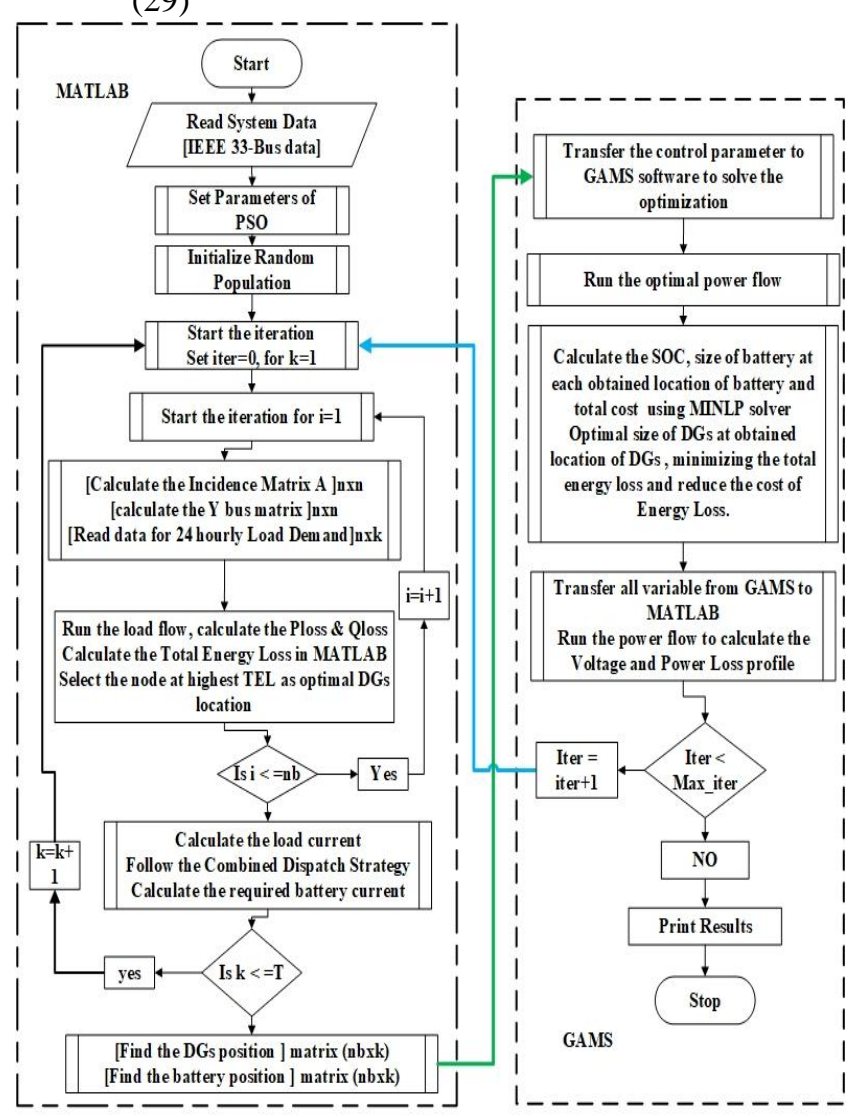

Figure 5 Flow chart for the proposed method

Step 5 Transfer the objective variables form GAMS to MATLAB.

(a) Get the results

Step 6 Print the results.

The flow chart of the proposed algorithm is shown in Figure 5.

\section{SYSTEM DATA}

The input data used in this paper has shown in Table-I. The cost estimation data for the PV-based DG and wind-based DG have been taken from the National Renewable Energy
Laboratory (NREL) [30], [31] \& [32]. The data for battery, regulators and investors are taken from the literature [12-13]. Table-I The input data for the energy sources [30], [31] \& [32].

\begin{tabular}{|c|c|c|c|c|c|}
\hline $\begin{array}{l}\text { Descript } \\
\text { ion }\end{array}$ & $\begin{array}{l}\text { Install } \\
\text { ation } \\
\text { cost (\$) }\end{array}$ & $\begin{array}{l}\text { Operati } \\
\text { on and } \\
\text { Mainten } \\
\text { ance } \\
\text { Cost } \\
\text { (\$/year/ } \\
\text { kW) }\end{array}$ & $\begin{array}{l}\text { Replace } \\
\text { ment } \\
\text { Cost } \\
\text { (\$/Lifeti } \\
\text { me) }\end{array}$ & $\begin{array}{l}\text { Lifesp } \\
\text { an } \\
\text { (year) }\end{array}$ & Rating \\
\hline $\begin{array}{l}\text { PV } \\
\text { module }\end{array}$ & 2400 & 18 & $\begin{array}{l}2.85 @ \\
25 \text { year } \\
\text { of life } \\
\text { time }\end{array}$ & 25 & $\begin{array}{l}800 \\
(\mathrm{~kW})\end{array}$ \\
\hline $\begin{array}{l}\text { Wind } \\
\text { Turbine } \\
\text { (1MW) }\end{array}$ & 3724.5 & 31 & 3009.5 & 20 & $\begin{array}{l}1000 \\
(\mathrm{~kW})\end{array}$ \\
\hline $\begin{array}{l}\text { Battery } \\
\text { Storage }\end{array}$ & 600 & 20 & $\begin{array}{l}4.64 @ \\
1.45 \text { year }\end{array}$ & 1.45 & $\begin{array}{l}100 \\
(\mathrm{kWh})\end{array}$ \\
\hline
\end{tabular}

\section{A. Load data}

The 24 hrs load variation at each bus has been taken for the study, and load variation is shown in Figure 6 . The reactive power demand is maximum at 31st bus, whereas the active power demand at bus number 24th and 25th respectively.

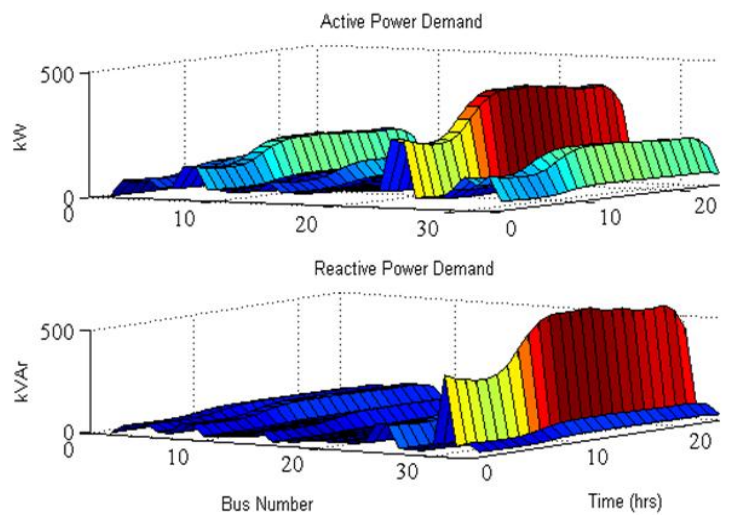

Figure 6 Load Demand for 24 hrs.

\section{B. PV Solar and Wind Data}

The solar irradiation data and the wind speed data are taken from the online mode, i.e. National Renewable Energy Laboratory (NREL) [30], [31] \& [32]. In Figure 7, the solar irradiation is shown.

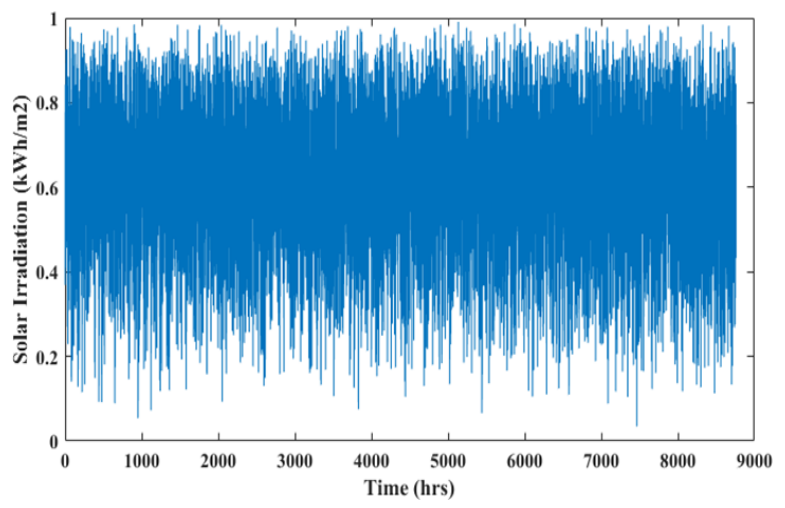

Figure 7. Hourly solar irradiation profile

Published By: Blue Eyes Intelligence Engineering and Sciences Publication

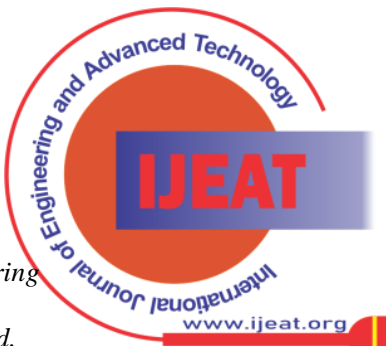
Exploring Innovation 


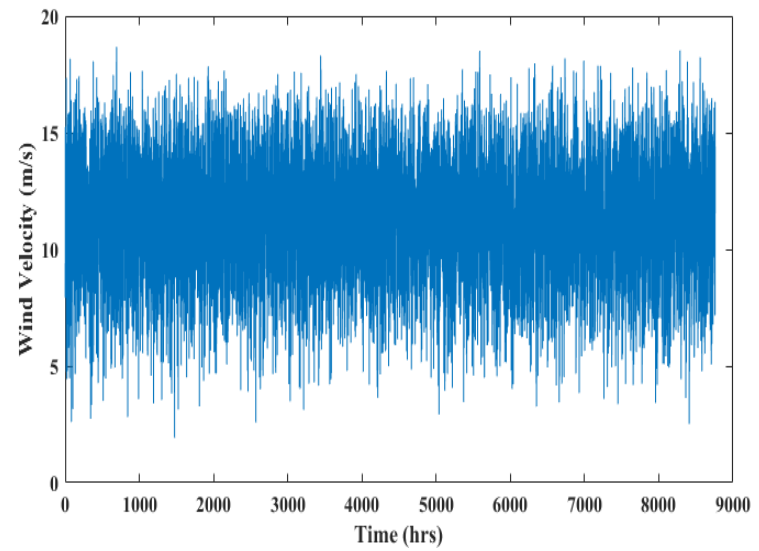

Figure 8 Hourly wind speed profile

In Figure 8, the hourly wind profile is shown. The cut of velocity $v_{\text {in }}$ of $2.6(\mathrm{~m} / \mathrm{s})$ and cut out wind velocity $v_{\text {out }}$ of 20 $(\mathrm{m} / \mathrm{s})$ are taken into account for the wind turbine operation.

\section{RESULTS AND DISCUSSIONS}

The results are obtained for the IEEE 33 bus radial distribution system having DGs along with the storage devices.

In objective (i), two cases with the base case have been taken as follows;

- Base Case: Without DGs and Battery storage devices.

- Case 1: Single DG with Battery Storage Devices.

- Case 2: Two DGs with Battery Storage Devices. The $12.66 \mathrm{kV}$ 33-bus IEEE test system along with sessional load variation, has been considered for the analysis. In objective (ii), two cases have been taken as follows;

- Case 3: Single DG with Battery Storage Devices.

- Case 4: Two DGs with Battery Storage Devices. The results and comparison have been shown in a further section.

\section{A. Results for Single Objective Function}

The results are obtained for IEEE-33 bus test system. The peak demand for the test system is $3715+\mathrm{j} 2300 \mathrm{kVA}$.

1) Results for Base Case

The load data is shown in Figure 6. The Daily energy demand for 24 hrs load variation is 73.9285 MWh. The minimum voltage found is $0.9037 \mathrm{pu}$ at bus number 18. The Daily energy loss for a day obtained is $2031.45 \mathrm{kWh}$. The annual cost of energy loss (CEL) obtained is 88,712.8 (€).

2) Case 1. Result for Single DG

a) Result for single DG without battery energy storage In this section, the size of DGs is determined without considering the BES. The DG of single-unit $2590 \mathrm{~kW}$ at $6^{\text {th }}$ bus, and two units of $864.8 \mathrm{~kW}$, and $1076.8 \mathrm{~kW}$ at bus $13^{\text {th }}$ and $30^{\text {th }}$ bus are obtained respectively using the proposed algorithm. Furthermore, the power loss profile for a single unit and two units of DG is depicted in Figure 9. The power loss is reduced to $110.10 \mathrm{~kW}$ and $87.36 \mathrm{~kW}$ with single and two units of DGs, respectively.

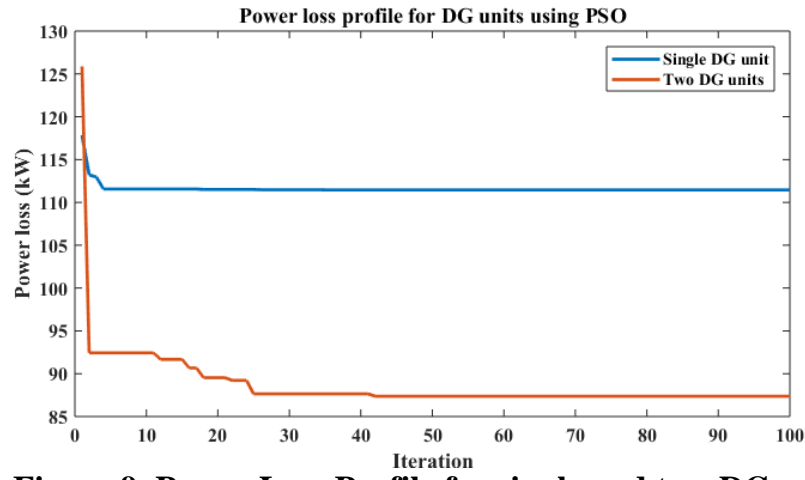

Figure 9. Power Loss Profile for single and two DG units with PSO algorithm

In addition, the Daily energy loss obtained without battery storage is $1950 \mathrm{kWh}$ for a single unit and $1750.56 \mathrm{kWh}$ for two units of DG, respectively for 24 hrs load variation.

Therefore, annual energy loss saving is increased to $€ 53022.5$.

b) Result for single DG with battery energy storage

The results obtained are superior to the proposed method is compared to another method in Table II. With using the battery energy storage, the DG size is reduced to $1479.7 \mathrm{~kW}$ from $2590 \mathrm{~kW}$ using the hybrid PSO and GAMS algorithm as given in Table II. The size of battery energy storage obtained is $116.74 \mathrm{kWh}$. The optimal location of battery storage is selected using a combined dispatch strategy. The maximum and minimum numbers of battery cell obtained are 8 and 4 , respectively.

The power loss is reduced to $110.55 \mathrm{~kW}$ with BES and DGs since the degradation loss in BES. However, the power loss is reduced to $110.10 \mathrm{~kW}$ using DG only. The daily energy loss obtained with battery storage and single DG is $1062.2 \mathrm{kWh}$ for $24 \mathrm{hrs}$ load variation. In addition, the power loss is reduced to $47.60 \%$ with DG and BES, as compared to the base case, which is slightly decreased to $47.60 \%$ from $47.80 \%$ with DG only. Therefore, annual energy loss saving is increased to $€ 52786.008$.

3) Case 2. Result for Two DGs.

a) Results for two DG units without battery energy storage In this scenario, the proposed algorithm has used the size of two DG units obtained are $864.80 \mathrm{~kW}$ at $13^{\text {th }}$ bus, and $1076.80 \mathrm{~kW}$ at $30^{\text {th }}$ bus, respectively. The power loss is reduced to $87.36 \mathrm{~kW}$ form $210.98 \mathrm{~kW}$ with compared to the base case. Therefore, the annual cost of energy loss saving is increased to $€ 64974.67$.

\section{b) Results for two DG units with battery energy storage}

The size of renewable-based DGs obtained are 655.74, 901.64 at 13th and 30th bus respectively. The total size of diesel generator obtained is $120 \mathrm{~kW}$, and the maximum size of battery storage is $58.368 \mathrm{kWh}$ at 30th bus.

The energy loss has been reduced from the base case of $2031.5 \mathrm{kWh}$ to $821.84 \mathrm{kWh}$ by using battery energy storage and DGs. The power loss is reduced to $85.9 \mathrm{~kW}$. Therefore the percentage of power loss reduction obtained is $59.28 \%$ with the base Case as given in Table III.

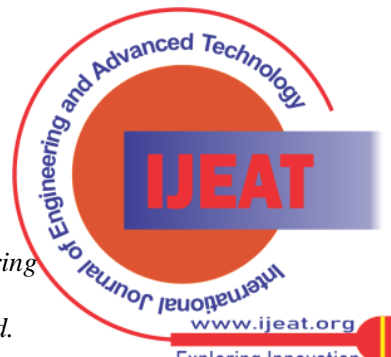


The daily energy loss obtained is $1750.56 \mathrm{kWh}$ using two DGs only, whereas daily energy loss obtained is $821.84 \mathrm{kWh}$ using two DGs and battery storage. Therefore, the annual cost of energy loss saving is increased to $€ 65742.048$.

\section{B. Results for multi-objective case}

The multi-objective function comprises of minimization of daily energy loss and the total cost of the system. The results are shown in Table-IV for the multi-objective function of Case- 3 and Case- 4 .

Table-IV Results for the multi-objective problem of Case-3 and Case-4.

\begin{tabular}{|c|c|c|c|}
\hline Descriptions & Case-3 & \multicolumn{2}{|c|}{ Case-4 } \\
\hline Total Cost of System (€) & $\begin{array}{l}147518.2 \\
1\end{array}$ & \multicolumn{2}{|c|}{130857.28} \\
\hline $\begin{array}{c}\text { Daily energy Demand for } 24 \text { hrs } \\
(\mathrm{kWh})\end{array}$ & 73929 & \multicolumn{2}{|c|}{73929} \\
\hline $\begin{array}{c}\text { Daily energy Loss in Base Case } \\
(\mathrm{kWh})\end{array}$ & 2031.49 & \multicolumn{2}{|c|}{2031.49} \\
\hline Daily energy Loss (kWh) & 1062.21 & \multicolumn{2}{|c|}{821.84} \\
\hline Location of DG at Bus number & 6 & 6 & 13 \\
\hline $\begin{array}{l}\text { Rated Wind Power Generation } \\
\text { (kW) }\end{array}$ & 1400 & - & $\begin{array}{c}100 \\
0\end{array}$ \\
\hline Rated PV solar Power (kW) & - & 800 & - \\
\hline Total Size of DG (kW) & 1400 & \multicolumn{2}{|c|}{1800} \\
\hline Total Size of Battery (kWh) & 1459.2 & \multicolumn{2}{|c|}{1164.288} \\
\hline $\begin{array}{c}\text { Number of Battery in Parallel and } \\
\text { Series }\end{array}$ & $4 \times 2$ & \multicolumn{2}{|c|}{$4 \mathrm{X1}$} \\
\hline Rated Diesel Generator (kW) & 4 & \multicolumn{2}{|c|}{4} \\
\hline Fuel used (liter/day) & 513 & \multicolumn{2}{|c|}{499.31} \\
\hline Total cost of PV (€) & - & \multicolumn{2}{|c|}{14265.27} \\
\hline Total cost of wind $(€)$ & 48760.6 & \multicolumn{2}{|c|}{34684.82} \\
\hline Total cost of Battery Storage ( $€$ ) & 34264 & \multicolumn{2}{|c|}{27339.065} \\
\hline $\begin{array}{c}\text { Grid Cost of electricity }(€) \text { for } \\
20 € / \mathrm{kWh}\end{array}$ & 83.21 & \multicolumn{2}{|c|}{6.2} \\
\hline Total cost for invertors $(€)$ & 64000 & \multicolumn{2}{|c|}{53760} \\
\hline $\begin{array}{c}\text { Total cost of regulators (€/per } \\
\text { unit) }\end{array}$ & - & \multicolumn{2}{|c|}{402.48} \\
\hline Fuel cost of Diesel Generator $(€)$ & 410.4 & \multicolumn{2}{|c|}{399.448} \\
\hline Annual cost of energy loss (€) & $\begin{array}{l}23262.39 \\
9\end{array}$ & \multicolumn{2}{|c|}{17998.296} \\
\hline $\begin{array}{l}\text { Annual cost of energy loss saving } \\
(€)\end{array}$ & $\begin{array}{l}21227.23 \\
2\end{array}$ & \multicolumn{2}{|c|}{26491.335} \\
\hline Power loss reduction & 47.712 & \multicolumn{2}{|c|}{59.544} \\
\hline
\end{tabular}

Comparing the results obtained for Case 3 and Case 4 , it is observed that a number of batteries and size obtained are more for Case 3 . The total cost of the system is lower for Case 4 compared to Case 3 . The power exchange with the grid is lower for Case 4 compared to Case 3 . The price of electricity taken is $2020 € / \mathrm{kWh}$. The power exchange with the grid is lower with case 4 . Therefore, the grid cost of electricity is lower for Case 4 compared to Case-3. The total size of BES is reduced to $1164.288 \mathrm{kWh}$ (case 4), from $1459.2 \mathrm{kWh}$ (case3) since the larger DG size of $1800 \mathrm{~kW}$ for case 4 . Thus the overall cost of the system is reduced to $€ 130857.28$ with case 4 , from $€ 147518.21$ with case 3 . In addition, the annual cost of energy loss saving obtained is $€ 21227.232$ and $€ 26491.335$ with case 3 and case 4 , respectively. The power loss is reduced to $47.712 \%$ with case 3 and $59.54 \%$ with case 4 . Therefore, case 4 has obtained better results as compared to the case 3 .

\section{Comparison of results with another existing algorithm}

In Table- $\mathrm{V}$, the simulation results with single, and two DG units are given, and the proposed method is compared with the PSO algorithm also. The results are compared with the proposed method and the PSO algorithm. The single DG of size $1355.7 \mathrm{~kW}$ is installed on the 6th bus. The total size of single DG with battery storage and diesel generator obtained is $1479.7 \mathrm{~kW}$ along with the battery of $116.74 \mathrm{kWh}$. Therefore the total power loss has been reduced to $47.606 \%$, and the CEL saving has achieved $(€) 42,228.80$. In the two DGs scenario, the DGs of $655.74 \mathrm{~kW}$ and $901.6394 \mathrm{~kW}$ are installed at the location of the 13th and 30th bus, respectively. Consequently, voltage regulation has been improved in the proposed technique in both the Cases of DG1 and DG2. Therefore the total power loss has been reduced along with the enhancement of voltage profile. The power loss obtained after the installation of two DGs is $85.908 \mathrm{~kW}$, and CEL saving is $(€)$ 52598.68, respectively. The currency change factor taken is 0.8 from Doller $(\$)$ into euro $(€)$. It is clear from Table-III and V; the results of the proposed hybrid algorithm are superior to other existing methods. By using the battery storage; the power loss, the required size of DG and CEL has been reduced with compared to other techniques. Therefore the battery storage is maximized the cost-saving of energy loss from $(€) 52,059.6$ to $(€) 52598.64$ in the network.

Table-V. The results for single and two DGs with and without BES

\begin{tabular}{|c|c|c|c|c|c|c|}
\hline \multirow{3}{*}{\begin{tabular}{|c|} 
\\
$\begin{array}{c}\text { Descriptio } \\
\text { n }\end{array}$ \\
\end{tabular}} & \multicolumn{3}{|c|}{ Single DG unit } & \multicolumn{3}{|c|}{ Two DG units } \\
\hline & \multicolumn{2}{|c|}{ Without BES } & \multirow{2}{*}{\begin{tabular}{|c|} 
With BES \\
PSO+ \\
GAMS
\end{tabular}} & \multicolumn{2}{|c|}{ Without BES } & \multirow{2}{*}{\begin{tabular}{|c} 
With BES \\
PSO+ \\
GAMS
\end{tabular}} \\
\hline & $\begin{array}{l}\text { PSO } \\
{[10]}\end{array}$ & $\begin{array}{l}\text { PSO+ } \\
\text { GAMS }\end{array}$ & & PSO [10] & $\begin{array}{l}\text { PSO+ } \\
\text { GAMS }\end{array}$ & \\
\hline $\begin{array}{l}\text { Location at } 6 \\
\text { bus }\end{array}$ & & 6 & 6 & 13,30 & 13,30 & 13,30 \\
\hline \multirow{2}{*}{\begin{tabular}{|c|} 
DG Size \\
$(\mathbf{k W})$
\end{tabular}} & \multirow[t]{2}{*}{2590} & \multirow[t]{2}{*}{2592.2} & \multirow[t]{2}{*}{1355.7} & 864.79 & 851.63 & 655.74 \\
\hline & & & & 1076.8 & 1157.58 & 901.63 \\
\hline \begin{tabular}{|c|} 
Total size \\
of Diesel \\
Gen $(k W)$ \\
\end{tabular} & & & 124 & & & 120 \\
\hline BES (kWh) & & & 116.7 & & & 630.9 \\
\hline DG total & 2590 & 2590.21 & 1479.7 & 1941.59 & 2009.21 & 1677.37 \\
\hline TPL (kW) & 110.1 & 110.3 & 110.5 & 87.36 & 87.16 & 85.9 \\
\hline \begin{tabular}{|c|} 
TPL \\
Reduction \\
$(\%)$
\end{tabular} & 47.81 & 47.68 & 47.60 & 58.59 & 58.68 & 59.28 \\
\hline $\begin{array}{c}\text { Min. V } \\
\text { (pu) }\end{array}$ & 0.94236 & 0.94239 & 0.9321 & 0.96611 & 0.96851 & 0.967 \\
\hline \begin{tabular}{|c|}
$\begin{array}{c}\text { Voltage } \\
\text { Deviation } \\
(\%)\end{array}$ \\
\end{tabular} & 2.798 & 2.796 & 3.296 & 2.127 & 2.050 & 2.101 \\
\hline $\begin{array}{l}\text { Annual } \\
\text { CEL (€) }\end{array}$ & \begin{tabular}{|c|}
57868.5 \\
6
\end{tabular} & 58015.73 & 58105.08 & \begin{tabular}{|l|l|}
45916.42 \\
\end{tabular} & 45814.98 & 45149.04 \\
\hline \begin{tabular}{|c|} 
Saving in \\
Annual \\
CEL (€) \\
\end{tabular} & $\begin{array}{c}53022.5 \\
3\end{array}$ & 52875.36 & 52786.01 & 64974.67 & 65076.11 & 65742.05 \\
\hline
\end{tabular}

The voltage profile for single and two DG units without BES is shown in Figure 10. The minimum voltage obtained is $0.90377 \mathrm{pu}, 0.94236 \mathrm{pu}$, and $0.94239 \mathrm{pu}$ for the base case, single DG using PSO, and single DG using PSO and GAMS, respectively.

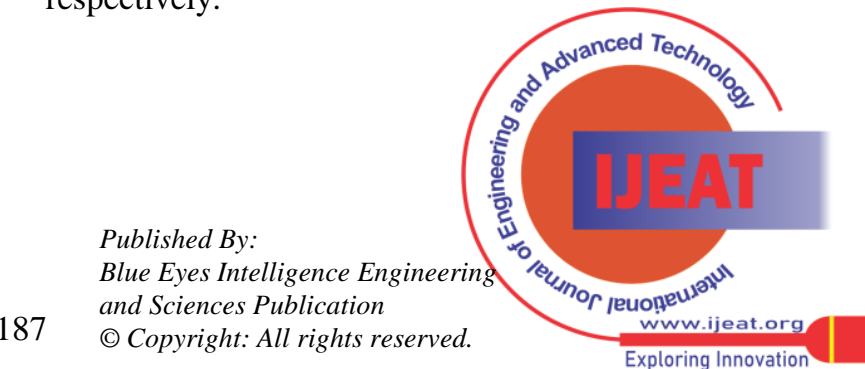


In addition, the minimum voltage of $0.96611 \mathrm{pu}$ and 0.96851pu is obtained for the PSO and proposed hybrid method for the two units of DG respectively.

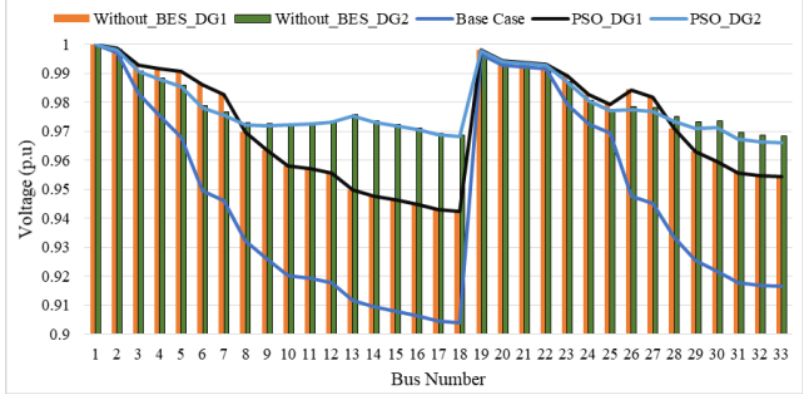

Figure 10. Voltage profile for single and two DG units without BES

D. The power output profile

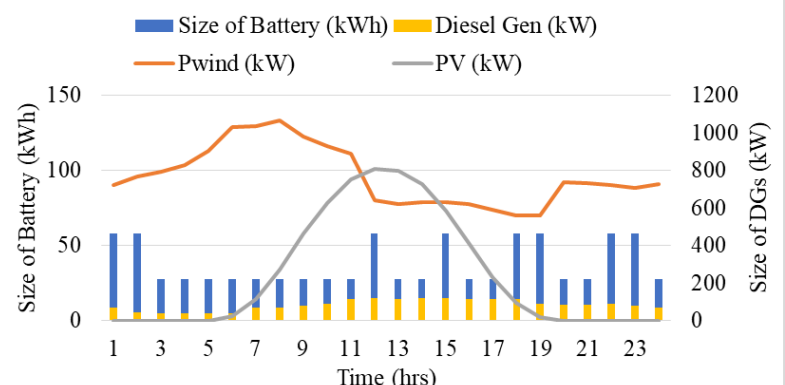

Figure 11. The output power of renewable DGs with battery storage devices and Diesel generator

In Figure 11, the output power of renewable-based DGs along with the battery storage and a diesel generator is shown for 24 hrs. The maximum power output of diesel generator is 200 $\mathrm{kW}$ at 12th, 14th and 15th hrs since the maximum load demand. The peak demand of $3715 \mathrm{~kW}$ has met at 11th hrs on the load curve. The wind generator of $1000 \mathrm{~kW}$ is installed at $30^{\text {th }}$ bus, whereas the PV solar is installed at $13^{\text {th }}$ bus to meet the load demand.

\section{E. Comparison of Results for Dispatch Strategy}

Table. VI describes the results of the dispatch strategies have been used in different methods. The combined dispatch strategy is used in this paper.

Table-VI. Results and comparison between different dispatch strategies and methods.

\begin{tabular}{|c|c|c|c|c|}
\hline $\begin{array}{l}\text { Description } \\
\text { s }\end{array}$ & $\begin{array}{l}\text { HOGA } \\
{[14]} \\
\text { (PV-Diesel } \\
\text { ) }\end{array}$ & $\begin{array}{l}\text { HOGA } \\
{[14]} \\
\text { (Diesel } \\
\text { Only) }\end{array}$ & $\begin{array}{l}\text { HOMAR } \\
{[14]} \\
\text { (PV } \\
\text { Diesel ) }\end{array}$ & $\begin{array}{l}\text { Purposed } \\
\text { Method } \\
\text { (PV + Diesel } \\
\text { + Batt) }\end{array}$ \\
\hline $\begin{array}{ll}\text { Size } & \text { of } \\
\text { Battery } & \\
(\mathrm{kWh}) & \\
\end{array}$ & 13.8 & 13.8 & 13.8 & 13.8 \\
\hline $\begin{array}{l}\text { Nominal } \\
\text { capacity of } \\
\text { Battery }\end{array}$ & $\begin{array}{l}2 \times 4 \text { panels } \\
\text { of } 144 \mathrm{Ah} \text {, } \\
12 \mathrm{~V}\end{array}$ & $\begin{array}{l}2 \times \\
\text { panels of } \\
144 \text { Ah, } \\
12 \mathrm{~V}\end{array}$ & $\begin{array}{l}2 \times 1 \\
\text { panels of } \\
144 \text { Ah, } \\
48 \mathrm{~V}\end{array}$ & $\begin{array}{l}2 \times 1 \text { panels } \\
\text { of } 144 \mathrm{Ah} \text {, } \\
48 \mathrm{~V}\end{array}$ \\
\hline $\begin{array}{l}\text { Charge } \\
\text { Regulator } \\
\text { Current (A) }\end{array}$ & 107 & 63 & - & 107 \\
\hline $\begin{array}{l}\text { Dispatch } \\
\text { Strategy }\end{array}$ & $\begin{array}{l}\text { Cycle } \\
\text { Charging }\end{array}$ & Combined & $\begin{array}{l}\text { Cycle } \\
\text { Charging }\end{array}$ & Combined \\
\hline $\begin{array}{l}\text { Critical } \\
\text { discharging } \\
\text { load (Ld in } \\
\text { W) }\end{array}$ & 2768 & 3391 & - & 3213.144 \\
\hline Critical & 1186 & 1452 & - & 1466.129 \\
\hline
\end{tabular}

\begin{tabular}{|l|l|l|l|l|}
\hline $\begin{array}{l}\text { charging } \\
\text { load (Lc in } \\
\text { W) }\end{array}$ & & & & \\
\hline $\begin{array}{l}\text { Battery } \\
\text { Replacement } \\
\text { Cycle (year) }\end{array}$ & 2.21 & 1.45 & 3.85 & 1.45 \\
\hline $\begin{array}{l}\text { Rated } \\
\begin{array}{l}\text { Capacity of } \\
\text { Diesel } \\
\text { Generator } \\
\text { (kW) }\end{array}\end{array}$ & & 4 & 4 & 4 \\
\hline $\begin{array}{l}\text { Total Net } \\
\text { Present cost } \\
(€)\end{array}$ & 162388 & 179938 & 168239 & 175886 \\
\hline
\end{tabular}

The maximum size of battery and diesel generator, location, and optimum cost has been obtained. The comparison between the effects of battery, diesel generator with the existing method is given in Table-VI. In the purposed method, the size of individual battery storage obtained is $13.8 \mathrm{kWh}$. There are two no's of batteries in series and one in parallel connected. The capacity of each battery is 144 Ah taken into account. The critical discharge load (Ld) and Critical charging load (Lc) are the decision parameters for obtaining the optimal location of battery and diesel generator. The (Ld) and (Lc) obtained are 3213.144 W and 1466.129 W for the location of the battery, respectively.

\section{F. The impact of battery storage}

In this section, the results with battery storage are shown in Table-VII. The impact of battery storage on the sizing of DGs and energy loss saving in the distribution network has demonstrated.

Table-VII: Impact of battery storage on DG's

\begin{tabular}{|c|c|c|c|}
\hline & \multirow[t]{2}{*}{ Without Battery } & \multicolumn{2}{|c|}{ With Battery } \\
\hline & & Size of DG $(\mathrm{kW})$ & $\begin{array}{l}\text { Size of } \\
\text { Battery }\end{array}$ \\
\hline $\begin{array}{c}\text { Size of DG-1 } \\
(\mathrm{kW})\end{array}$ & $\begin{array}{c}2590.21 @ \text { bus } \\
\text { no.6 }\end{array}$ & $\begin{array}{l}\text { 1355.7@ bus no.6 } \\
+124 \text { @ Diesel Gen } \\
\end{array}$ & $\begin{array}{l}116.74 \\
(\mathrm{kWh}) \\
\end{array}$ \\
\hline $\begin{array}{c}\text { Energy Loss } \\
\text { (kWh) with } \\
\text { DG-1 }\end{array}$ & 1950 & 1062.2 & \\
\hline $\begin{array}{l}\text { Size of DG-2 } \\
(\mathrm{kW})\end{array}$ & $\begin{array}{c}851.63 @ \text { @ bus } \\
\text { no. } 13 \\
1157.58 @ \text { bus } \\
\text { no. } 30\end{array}$ & $\begin{array}{c}655.74 @ \text { bus no. } \\
30 \\
901.63 @ \text { bus no. } \\
30 \\
+120 @ \text { Diesel Gen }\end{array}$ & 58.36 (kWh) \\
\hline $\begin{array}{c}\text { Energy Loss } \\
\text { with DG-2 } \\
(\mathrm{kWh})\end{array}$ & 1750.56 & 821.84 & \\
\hline
\end{tabular}

G. Voltage Profile and Power Loss

The proposed algorithm has been used to obtain the voltage regulation also. The minimum voltage of Case 1 and Case 2 for 24 hrs load variation is shown in Figure12.
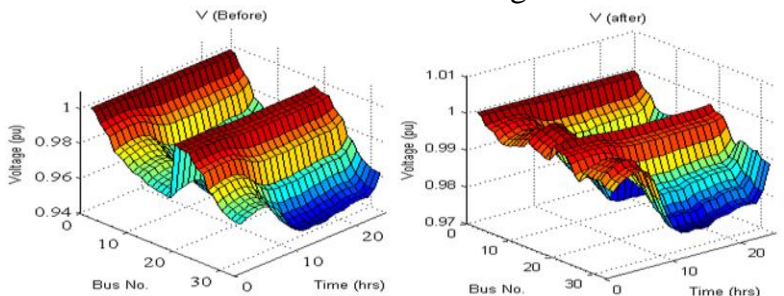

Figure 12. Voltage profile for $\mathbf{2 4}$ hrs load variation for IEEE 33-bus system

Published By:

Blue Eyes Intelligence Engineering and Sciences Publication 
The minimum voltage obtained is 0.9635 pu across 18th bus at 12 th hours for Case- 1 . The minimum voltage obtained is 0.9766 pu across 33rd bus at12th hrs for Case- 2 .

In Figure 13, the minimum voltage profile for 33 bus systems, is considered for $24 \mathrm{hrs}$ load variation. The voltage profile has enhanced for Case- 2 and Case- 1 as compare with the base Case.

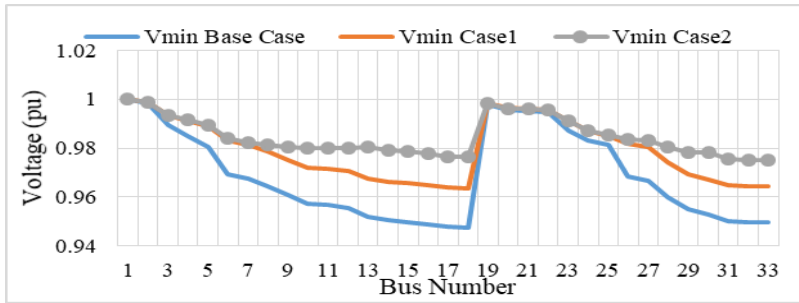

Figure 13. Minimum voltage profile for various case study

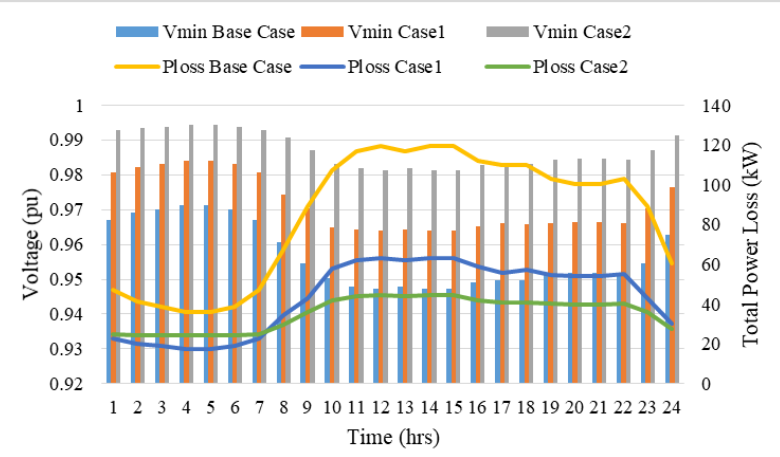

Figure14. Power loss and voltage profile for 24 hrs load variation

The total power loss and improved voltage profile have been shown in Figure14 for 24 hrs load variation. The highest voltage at 5th hrs and lowest at 12th hrs have been obtained for each case. The total power loss has been reduced by increasing the numbers of DGs. Therefore, in Case2; the real power loss and voltage profile have superior results with other Cases. The minimum power loss has obtained with Case-2 at 4 th hrs, whereas the highest power loss obtained at 15th hrs.

\section{CONCLUSION}

This paper represents the hybrid PSO and GAMS optimization using MATLAB and GAMS interfacing to solve the multi-objective problem. This study provides the optimal sizing and siting of battery storage with the integration of renewable sources to minimize the Daily energy loss and cost of the system also. The proposed hybrid algorithm has solved in two parts. (i) In the first part, the PSO algorithm, along with a combined dispatch strategy, has been addressed to obtain the location of DGs and battery storage. (ii) The MINLP algorithm in GAMS has been solved to get the size of DGs and battery storage.

This study is provided with the integrations of renewable-based DGs along with battery storage to minimize Daily energy loss, operation and maintenance cost of DGs, CEL, and enhanced the voltage profile. The simulated results have carried out four Cases. In Case-1, the size of single DG, diesel generator, and battery storage obtained are 1355.676 $\mathrm{kW}, 124 \mathrm{~kW}$, and $116.736 \mathrm{kWh}$ respectively. The power loss has been reduced to $47.713 \%$, and The CEL saving achieved is $(€)$ 52,786.0. On the other hand, in Case-2: the size of two DGs, diesel generator, and battery storage obtained are $655.74 \mathrm{~kW}, 901.6394 \mathrm{~kW} 120 \mathrm{~kW}$, and $58.368 \mathrm{kWh}$ respectively. The power loss has been reduced to $59.547 \%$, and the CEL saving obtained is $(€)$ 65,748.3. The Daily energy loss and cost of the system have minimized with two DGs. In Case-3 and Case-4, the multi-objective problem has evaluated. The total cost of the system for Case-3 and Case-4 obtained are $(€) 136244.09$ and $(€) 120433.89$, respectively. Therefore, the total cost of the system has been reduced in Case-4. This study provides the optimal economic coordination of DGs along with the battery storage to reduce the losses.The impact of battery storage on the size of DGs and energy saving is as follows: (i) the size of single DG has been reduced from 2590.21 to $1479.7 \mathrm{~kW}$ respectively and (ii) the energy loss has been reduced from $1950 \mathrm{kWh}$ to 1062.2 kWh DG with and without battery storage respectively. (iii) The total size of two DGs has been reduced from $2009.21 \mathrm{~kW}$ to $1677.3 \mathrm{~kW}$ and (iv) the energy loss has been reduced from $1750.56 \mathrm{kWh}$ to $821.84 \mathrm{kWh}$ respectively with and without battery storage. The hybrid optimization and combined dispatch approach have provided efficient installation of battery storage with the optimal economical operation of DGs. The best combination for economical operation and loss minimization obtained is, PV-based, wind-based, diesel generator + battery storage.

Table-II Comparison of results with other existing results for single DGs

\begin{tabular}{|c|c|c|c|c|c|c|c|c|c|}
\hline \multirow[t]{2}{*}{ Description } & \multirow[t]{2}{*}{ Base Case } & \multirow{2}{*}{$\begin{array}{l}\text { GABC } \\
{[10]}\end{array}$} & \multirow{2}{*}{$\begin{array}{l}\text { KHAAQ } \\
4[3]\end{array}$} & \multirow[t]{2}{*}{ SKHA [3] } & \multirow{2}{*}{$\begin{array}{l}\text { GABC } \\
{[4]}\end{array}$} & \multirow{2}{*}{$\begin{array}{l}\text { Dragonfl } \\
\text { y [5] }\end{array}$} & \multirow{2}{*}{$\begin{array}{l}\text { GA\& } \\
\text { TOPSIS } \\
{[33]}\end{array}$} & \multicolumn{2}{|c|}{ Proposed GAMS+PSO } \\
\hline & & & & & & & & $\begin{array}{l}\text { Without } \\
\text { BES }\end{array}$ & With BES \\
\hline DG Size $(\mathrm{kW})$ & ---- & 1543 & 2590.21 & 2590.21 & 1543 & 2590.2 & 1911 & 2590 & $\begin{array}{l}\text { 1355.7@ } \\
\text { DG+124@ } \\
\text { Diesel Gen } \\
+116.74 \text { kWh } \\
\text { @BES }\end{array}$ \\
\hline $\begin{array}{l}\text { DG total size } \\
(\mathrm{kW})\end{array}$ & ----- & 1543 & 2590.21 & 2590.21 & 1543 & 2590.2 & 1911 & 2590 & 1479.7 \\
\hline \multicolumn{5}{|c|}{$\begin{array}{l}\text { Retrieval Number: } 100.1 / \text { ijeat.C22650210321 } \\
\text { DOI:10.35940/ijeat.C2265.0210321 } \\
\text { Journal Website: } \underline{\text { ww.ijeat.org }}\end{array}$} & \multicolumn{3}{|c|}{$\begin{array}{l}\text { Published By: } \\
\text { Blue Eyes Intelligence Engineeri } \\
\text { and Sciences Publication } \\
\text { (C) Copyright: All rights reserved. }\end{array}$} & & \\
\hline
\end{tabular}




\begin{tabular}{|c|c|c|c|c|c|c|c|c|c|}
\hline $\begin{array}{l}\text { Location at } \\
\text { bus }\end{array}$ & ----- & 30 & 6 & 6 & 30 & 6 & 8 & 6 & 6 \\
\hline $\begin{array}{ll}\begin{array}{l}\text { Power } \\
(\mathrm{kW})\end{array} & \text { loss } \\
\end{array}$ & 210.98 & 125.15 & 111.01 & 111.01 & 125.15 & 111.03 & 118 & 110.10 & 110.55 \\
\hline $\begin{array}{l}\text { Power loss } \\
\text { reduction (\%) }\end{array}$ & ----- & 40.68 & 47.38 & 47.38 & 40.68 & 47.37 & 44.07 & 47.81 & 47.60 \\
\hline $\begin{array}{l}\text { Minimum } \\
\text { voltage (pu) }\end{array}$ & 0.9 & 0.927 & 0.9424 & 0.9424 & 0.927 & 0.9424 & 0.9448 & 0.942363 & 0.9321 \\
\hline $\begin{array}{l}\text { Voltage } \\
\text { regulation } \\
(\%) \\
\end{array}$ & ----- & 7.3 & 5.73 & 5.76 & 7.3 & 5.76 & 5.52 & 5.7637 & 6.78 \\
\hline $\begin{array}{l}\text { Annual Cost } \\
\text { of energy loss } \\
(€)\end{array}$ & 110891.08 & 65778.84 & $\begin{array}{l}58346.85 \\
6\end{array}$ & 58346.856 & $\begin{array}{l}65778.8 \\
4\end{array}$ & 58357.368 & 62020.8 & 57868.56 & 58105.08 \\
\hline $\begin{array}{l}\text { Annual cost } \\
\text { of energy loss } \\
\text { saving }(€)\end{array}$ & ----- & 45112.24 & 52544.23 & 52544.23 & $\begin{array}{l}45112.2 \\
4\end{array}$ & 52533.72 & 48870.28 & 53022.52 & 52786.008 \\
\hline
\end{tabular}

Table-III Comparison of results with other methods for two units of DGs with and without BES

\begin{tabular}{|c|c|c|c|c|c|c|c|c|}
\hline \multirow[t]{2}{*}{ Description } & \multirow{2}{*}{$\begin{array}{l}\text { Base } \\
\text { Case }\end{array}$} & \multirow[t]{2}{*}{ KHA [3] } & \multirow{2}{*}{$\begin{array}{l}\text { WIPSO-GSA } \\
{[34]}\end{array}$} & \multirow{2}{*}{$\begin{array}{l}\text { SKHA } \\
{[3]}\end{array}$} & \multirow{2}{*}{$\begin{array}{l}\text { HGWOAQ4 } \\
{[35]}\end{array}$} & \multirow{2}{*}{$\begin{array}{l}\text { GA\& } \\
\text { TOPSIS } \\
{[33]}\end{array}$} & \multicolumn{2}{|r|}{ Proposed } \\
\hline & & & & & & & $\begin{array}{l}\text { Without } \\
\text { BES }\end{array}$ & $\begin{array}{l}\text { With BES using } \\
\text { GAMS+PSO }\end{array}$ \\
\hline \multirow[t]{3}{*}{ DG Size (kW) } & & 1241.71 & 850 & 851.63 & 852 & 846 & 864.79 & 901.74 \\
\hline & & 824.48 & 1140 & 1157.58 & 1158 & 1150 & 1076.8 & 655.74 \\
\hline & & & & & & & & $\begin{array}{lll}630.9 & (\mathrm{kWh}) & @ B E S \\
+15.40 & (\mathrm{~kW}) @ & \text { Diesel } \\
\text { Gen } & & \\
\end{array}$ \\
\hline $\begin{array}{l}\text { Total size of DGs } \\
(\mathrm{kW})\end{array}$ & 0 & 2066.19 & 1990 & 2009.21 & 2010 & 1996 & 1941.59 & 1677.37 \\
\hline Location of DGs & & 29,30 & 13,30 & 13,30 & 13,30 & 13,30 & 13,30 & 13,30 \\
\hline Power loss (kW) & 210.98 & 87.42 & 87.17 & 87.16 & 87.16 & 87.17 & 87.36 & 85.9 \\
\hline $\begin{array}{l}\text { Power loss reduction } \\
(\%)\end{array}$ & 0 & $\begin{array}{l}58.5647 \\
9 \\
\end{array}$ & 58.68329 & $\begin{array}{l}58.6880 \\
3 \\
\end{array}$ & 58.68803 & 58.68329 & 58.593 & 59.285 \\
\hline $\begin{array}{l}\text { Minimum voltage } \\
\text { (pu) }\end{array}$ & 0.9 & 0.9667 & 9679 & 0.9684 & 0.9684 & 0.9687 & $\begin{array}{l}0.96851 \\
2\end{array}$ & 0.967 \\
\hline $\begin{array}{l}\text { Voltage regulation } \\
(\%)\end{array}$ & & 3.33 & 3.21 & 3.16 & 3.16 & 3.17 & $\begin{array}{l}3.14878 \\
6\end{array}$ & 3.296 \\
\hline $\begin{array}{l}\text { Annual Cost of } \\
\text { energy loss }(€)\end{array}$ & $\begin{array}{l}110891 . \\
1\end{array}$ & $\begin{array}{l}45947.9 \\
5\end{array}$ & 45816.55 & 45811.3 & 45811.3 & 45816.55 & $\begin{array}{l}5916.4 \\
2\end{array}$ & 45149.04 \\
\hline $\begin{array}{l}\text { Annual Cost of } \\
\text { energy loss saving } \\
(€)\end{array}$ & 0 & $\begin{array}{l}64943.1 \\
4\end{array}$ & 65074.54 & $\begin{array}{l}65079.7 \\
9\end{array}$ & 65079.79 & 65074.54 & $\begin{array}{l}64974.6 \\
7\end{array}$ & 65742.048 \\
\hline
\end{tabular}

\section{List of Symbols}

\begin{tabular}{|c|c|c|c|c|c|c|c|}
\hline$P_{\text {seler }}$ & $\begin{array}{l}\text { Solar output } \\
\text { power }\end{array}$ & $P_{\text {wind }}$ & $\begin{array}{l}\text { Wind output } \\
\text { power }\end{array}$ & $P_{\text {diti }}$ & $\begin{array}{l}\text { Charge power } \\
\text { for } \mathrm{i}^{\text {th }} \text { bus at } \mathrm{k}^{\text {th }} \\
\text { time }\end{array}$ & $A, B$ & Fuel curve constant \\
\hline$N P V$ & $\begin{array}{l}\text { Net present } \\
\text { value }\end{array}$ & $N_{\min f}$ & $\begin{array}{l}\text { Number of } \\
\text { wind Turbine }\end{array}$ & $L_{\text {wee }}$ & $\begin{array}{l}\text { Cycle charging } \\
\text { coefficient }\end{array}$ & $P_{\text {NGen }}$ & Rated power of Diesel Generator \\
\hline$F F$ & Fill factor & $v_{\text {fif }}$ & $\begin{array}{ll}\text { Cut } & \text { in } \\
\text { velocity } & \text { of } \\
\text { wind, } & \end{array}$ & $P d_{\text {matiesed }}$ & $\begin{array}{l}\text { Net DC load for } \\
\mathrm{i}^{\text {th }} \text { bus at } \mathrm{k}^{\text {th }} \text { time }\end{array}$ & $p f_{\text {ffeg }_{i}}$ & Power factor of Diesel Generator \\
\hline$V$ & Rated Voltage & $v_{\text {exit }}$ & $\begin{array}{lr}\text { cut } & \text { out } \\
\text { velocity } & \text { of } \\
\text { wind, } & \end{array}$ & $S_{D Q}$ & $\begin{array}{l}\text { Set of DG } \\
\text { location }\end{array}$ & $L_{\text {ifegy }}$ & $\begin{array}{l}\text { Net cost coefficient of Diesel } \\
\text { Generator }\end{array}$ \\
\hline$N_{F Y}$ & $\begin{array}{l}\text { Total number } \\
\text { of the solar } \\
\text { panel }\end{array}$ & $S O C_{\min }$ & $\begin{array}{l}\text { minimum } \\
\text { state of charge }\end{array}$ & $S_{\text {E }}$ & $\begin{array}{l}\text { Set of Battery } \\
\text { location }\end{array}$ & $P r_{\text {pued }}$ & Fuel price for Diesel Generator \\
\hline $\bar{i}$ & Index for bus & $S O C_{\max }$ & $\begin{array}{l}\text { maximum } \\
\text { state of chare }\end{array}$ & $n b$ & $\begin{array}{l}\text { Total number of } \\
\text { buses }\end{array}$ & $\delta_{i}$ & Voltage angle at bus i \\
\hline $\boldsymbol{k}$ & Index for time & $\boldsymbol{N}_{\text {liant }}$ & $\begin{array}{l}\text { total number } \\
\text { of battery }\end{array}$ & $P_{\text {disti }_{\text {in }}}$ & $\begin{array}{l}\text { Discharge } \\
\text { power for } \mathrm{i}^{\text {th }} \text { bus } \\
\text { at } \mathrm{k}^{\text {th }} \text { time }\end{array}$ & $D O D_{\max \_-1}$ & $\begin{array}{l}\text { maximum depth of discharge of } \\
\text { battery }\end{array}$ \\
\hline $\begin{array}{l}\text { ieval } \mathrm{Nu} \\
10.359 \\
\text { nal Web }\end{array}$ & $\begin{array}{l}\text { 100.1/ijeat.C2 } \\
\text { t.C2265.0210 } \\
\text { vww.ijeat.org }\end{array}$ & 0210321 & & 190 & \multicolumn{3}{|c|}{$\begin{array}{l}\text { Published By: } \\
\text { Blue Eyes Intelligence Engineeri } \\
\text { and Sciences Publication } \\
\text { (C) Copyright: All rights reserved }\end{array}$} \\
\hline
\end{tabular}




\section{REFERENCES}

1. H. T. Le and T. Q. Nguyen, "Sizing energy storage systems for wind power firming: An analytical approach and a cost-benefit analysis," IEEE Power Energy Soc. 2008 Gen. Meet. Convers. Deliv. Electr. Energy 21st Century, PES, no. ii, pp. 1-8, 2008, doi: 10.1109/PES.2008.4596223.

2. D. Q. Hung, N. Mithulananthan, and K. Y. Lee, "Optimal placement of dispatchable and nondispatchable renewable DG units in distribution networks for minimizing energy loss," Int. J. Electr. Power Energy Syst., vol. 55, pp. 179-186, 2014, doi: 10.1016/j.ijepes.2013.09.007.

3. S. A. ChithraDevi, L. Lakshminarasimman, and R. Balamurugan, "Stud Krill herd Algorithm for multiple DG placement and sizing in a radial distribution system," Engineering Science and Technology, an International Journal, vol. 20, no. 2. pp. 748-759, 2017, doi: 10.1016/j.jestch.2016.11.009.

4. M. Dixit, P. Kundu, and H. R. Jariwala, "Incorporation of distributed generation and shunt capacitor in radial distribution system for techno-economic benefits," Engineering Science and Technology, an International Journal, vol. 20, no. 2. pp. 482-493, 2017, doi: 10.1016/j.jestch.2017.01.003.

5. M. C. V. Suresh and E. J. Belwin, "Optimal DG placement for benefit maximization in distribution networks by using Dragonfly algorithm,' Renewables Wind. Water, Sol., vol. 5, no. 1, 2018, doi: 10.1186/s40807-018-0050-7.

6. S. Xie, X. Wang, C. Qu, X. Wang, and J. Guo, "Impacts of different wind speed simulation methods on conditional reliability indices," Int. Trans. Electr. energy Syst., vol. 20, no. April 2015, pp. 1-6, 2013, doi: 10.1002/etep.

7. R. Viral and D. K. Khatod, "An analytical approach for sizing and siting of DGs in balanced radial distribution networks for loss minimization," International Journal of Electrical Power and Energy Systems, vol. 67. pp. 191-201, 2015, doi: 10.1016/j.ijepes.2014.11.017.

8. E. Bompard, E. Carpaneto, G. Chicco, and R. Napoli, "Convergence of the backward/forward sweep method for the load-flow analysis of radial distribution systems,” Int. J. Electr. Power Energy Syst., vol. 22, no. 7, pp. 521-530, 2000, doi: 10.1016/s0142-0615(00)00009-0.

9. V. V. V. S. N. Murty and A. Kumar, "Optimal DG integration and network reconfiguration in microgrid system with realistic time varying load model using hybrid optimisation," IET Smart Grid, vol. 2, no. 2, pp. 192-202, 2019, doi: 10.1049/iet-stg.2018.0146.

10. P. Mehta, P. Bhatt, and V. Pandya, "Optimal selection of distributed generating units and its placement for voltage stability enhancement and energy loss minimization," Ain Shams Eng. J., vol. 9, no. 2, pp. 187-201, 2018, doi: 10.1016/j.asej.2015.10.009.

11. S. Kaur, G. Kumbhar, and J. Sharma, "A MINLP technique for optimal placement of multiple DG units in distribution systems,” Int. J. Electr. Power Energy Syst., vol. 63, pp. 609-617, 2014, doi: 10.1016/j.ijepes.2014.06.023.

12. U. ManDna and S. K. Goswami, "Optimum placement of distributed generation considering economics as well as operational issues," Int. Trans. Electr. Energy Syst., no. April 2019, pp. 1-20, 2020, doi: 10.1002/2050-7038.12246.

13. Y. M. Atwa, E. F. El-Saadany, M. M. A. Salama, R. Seethapathy, M. Assam, and S. Conti, "Adequacy evaluation of distribution system including wind/solar DG during different modes of operation," IEEE Trans. Power Syst., vol. 26, no. 4, pp. 1945-1952, 2011, doi: 10.1109/TPWRS.2011.2112783.

14. R. Dufo-López and J. L. Bernal-Agustín, "Design and control strategies of PV-diesel systems using genetic algorithms," Sol. Energy, vol. 79, no. 1, pp. 33-46, 2005, doi: 10.1016/j.solener.2004.10.004.

15. B. Dey, S. K. Roy, and B. Bhattacharyya, "Solving multi-objective economic emission dispatch of a renewable integrated microgrid using latest bio-inspired algorithms," Eng. Sci. Technol. an Int. J., vol. 22, no. 1, pp. 55-66, 2019, doi: 10.1016/j.jestch.2018.10.001.

16. D. Suchitra, R. Jegatheesan, and T. J. Deepika, "Optimal design of hybrid power generation system and its integration in the distribution network," Int. J. Electr. Power Energy Syst., vol. 82, pp. 136-149, 2016, doi: 10.1016/j.ijepes.2016.03.005.

17. Y. Yang, S. Bremner, C. Menictas, and M. Kay, "Battery energy storage system size determination in renewable energy systems: A review," Renew. Sustain. Energy Rev., vol. 91, no. June 2017, pp. 109-125, 2018, doi: 10.1016/j.rser.2018.03.047.

18. C. Chen, S. Duan, T. Cai, B. Liu, and G. Hu, "Optimal allocation and economic analysis of energy storage system in microgrids," IEEE

Trans. Power Electron., vol. 26, no. 10, pp. 2762-2773, 2011, doi

19. T. A. Nguyen, M. L. Crow, and A. C. Elmore, "Optimal sizing of a vanadium redox battery system for microgrid systems," IEEE Trans. Sustain. Energy, vol. 6, no. 3, pp. 729-737, 2015, doi: 10.1109/TSTE.2015.2404780.

20. M. Yue and X. Wang, "Grid Inertial Response-Based Probabilistic Determination of Energy Storage System Capacity Under High Solar Penetration," IEEE Trans. Sustain. Energy, vol. 6, no. 3, pp. 1039-1049, 2015, doi: 10.1109/TSTE.2014.2328298.

21. M. Korpaas, A. T. Holen, and R. Hildrum, "Operation and sizing of energy storage for wind power plants in a market system," Int. J. Electr. Power Energy Syst., vol. 25, no. 8, pp. 599-606, 2003, doi 10.1016/S0142-0615(03)00016-4

22. B. Bahmani-Firouzi and R. Azizipanah-Abarghooee, "Optimal sizing of battery energy storage for micro-grid operation management using a new improved bat algorithm," Int. J. Electr. Power Energy Syst., vol. 56, pp. 42-54, 2014, doi: 10.1016/j.ijepes.2013.10.019.

23. H. Saboori, R. Hemmati, and M. A. Jirdehi, "Reliability improvement in radial electrical distribution network by optimal planning of energy storage systems," Energy, vol. 93, pp. 2299-2312, 2015, doi: 10.1016/j.energy.2015.10.125

24. T. Kerdphol, Y. Qudaih, and Y. Mitani, "Battery energy storage system size optimization in microgrid using particle swarm optimization," IEEE PES Innov. Smart Grid Technol. Conf. Eur., vol. 2015-Janua, no. January, pp. 1-6, 2015, doi: 10.1109/ISGTEurope.2014.7028895.

25. X. Y. Wang, D. M. Vilathgamuwa, and S. S. Choi, "Determination of battery storage capacity in energy buffer for wind farm," IEEE Trans. Energy Convers., vol. 23, no. 3, pp. 868-878, 2008, doi: 10.1109/TEC.2008.921556.

26. S. A. Bozorgavari, J. Aghaei, S. Pirouzi, V. Vahidinasab, H. Farahmand, and M. Korpås, "Two-stage hybrid stochastic/robust optimal coordination of distributed battery storage planning and flexible energy management in smart distribution network," J. Energy Storage, vol. 26, no. 120, p. 100970, 2019, doi: 10.1016/j.est.2019.100970.

27. J. Kennedy and R. C. Eberhart, "Discrete binary version of the particle swarm algorithm,” Proc. IEEE Int. Conf. Syst. Man Cybern., vol. 5, pp. 4104-4108, 1997, doi: 10.1109/icsmc.1997.637339.

28. V. V. S. N. M. Vallem, "Optimal energy dispatch in microgrids with renewable energy sources and demand response," no. August 2019, pp 1-27, 2020, doi: 10.1002/2050-7038.12328.

29. A. S. Aziz, M. F. N. Tajuddin, M. R. Adzman, M. A. M. Ramli, and S. Mekhilef, "Energy management and optimization of a PV/diesel/battery hybrid energy system using a combined dispatch strategy," Sustain., vol. 11, no. 3, 2019, doi: 10.3390/su11030683.

30. L. A. Bird, K. S. Cory, and B. G. Swezey, "Renewable Energy August, 2008.

31. IRENA International Renewable Energy Agency, Renewable Powe Generation Costs in 2017. 2018.

32. N. R. E. Laboratory, "Distributed Generation Renewable Energy Estimate of Costs Database," 2013, [Online]. Available: http://www.nrel.gov/analysis/tech_lcoe_re_cost_est.html.

33. T. Sattarpour, D. Nazarpour, S. Golshannavaz, and P. Siano, "A multi-objective hybrid GA and TOPSIS approach for sizing and siting of DG and RTU in smart distribution grids," J. Ambient Intell Humaniz. Comput., vol. 9, no. 1, pp. 105-122, 2018, doi 10.1007/s12652-016-0418-8.

34. A. Rajendran and K. Narayanan, "Optimal multiple installation of DG and capacitor for energy loss reduction and loadability enhancement in the radial distribution network using the hybrid WIPSO-GSA algorithm,” Int. J. Ambient Energy, vol. 41, no. 2, pp. 129-141, 2020 doi: 10.1080/01430750.2018.1451371.

35. R. Sanjay, T. Jayabarathi, T. Raghunathan, V. Ramesh, and N hybrid grey Wolf optimizer," IEEE Access, vol. 5, pp. 14807-14818, 2017, doi: 10.1109/ACCESS.2017.2726586.

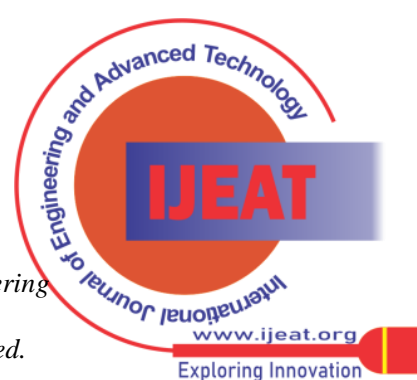




\section{AUTHORS PROFILE}

Bharat Singh Received his B.Tech degree form GBPEC Pauri, UK in 2012

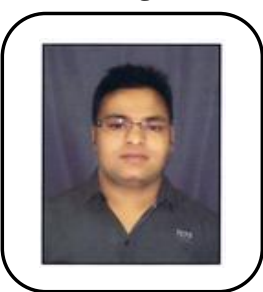
and M.Tech degree from NIT Hamirpur, India in 2016. He is currently pursuing Ph.D. from Electrical Engineering department in NIT Kurukshetra from 2018. His area of interest includes the dispatch strategy of Micro-Grid. He is life time member of Indian Society for Technical Education (ISTE) and Member of (IEEE). He has published 5 research articles in various international journals and conferences.

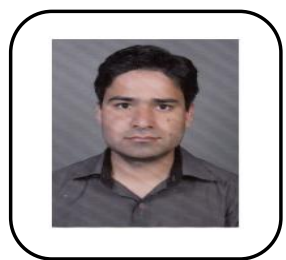

Satyaveer Singh Rawat Received his Bachelor of Engineering degree in Electrical Engineering form GBPEC Pauri, Uttarakhand, India in 2008 and M.Tech degree from IIT Khargpur, India in Power \& Energy specialization of Department of Electrical Engineering in 2015. He is currently working as an Assistant Professor in Department of Electrical Engineering at G.B. Pant Institute of Engineering \& Technology (formerly GBPEC) since 2009. His area of interest includes Distributed Generation and Integration with grid ,Wind Energy Integration with Grid, Solar PV Technology, Smart Grid and Micro Grid Operations, Operation of Grid Connected Microgrid, Operation of Islanded Microgrid. He is life time member of Indian Society for Technical Education (ISTE).

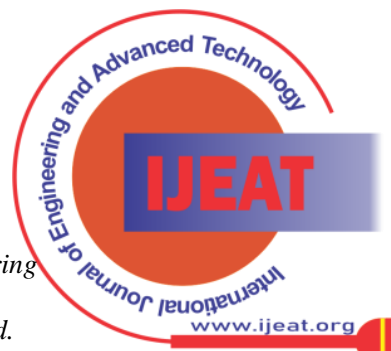

